\title{
Chemical Composition and Pulp Properties of Abaca (Musa textilis N'ee) cv. Inosa Harvested at Different Stages of Stalk Maturity
}

\author{
Luz O. Moreno ${ }^{1}$ and Calixto M. Protacio ${ }^{2}$
}

${ }^{1}$ National Abaca Research Center, Visayas State University, Baybay City, Leyte, 6521-A Philippines, ${ }^{2}$ Department of Horticulture, Crop Science Cluster, College of Agriculture, University of the Philippines Los Baños, College, Laguna, 4031 Philippines

\begin{abstract}
Given the increasing global demand for pulp, there is a need to look into the prospects of increasing fiber production and shortening the harvesting cycle of abaca without sacrificing the quality of fibers for pulp production. This study investigated the chemical and pulp properties of abaca cv. Inosa fibers harvested at different stages of stalk maturity to determine their suitability for pulp and paper production.

Fibers obtained from 8-10-month-old (immature) abaca cv. Inosa possessed the desirable chemical properties for pulping, namely; low lignin and ash content, high alpha-cellulose, holocellulose and hemicellulose contents; which are comparable with those obtained from intermediate and mature stalks. The average pulp yield, Kappa number, viscosity, tear index and breaking length of pulps from immature stalks were already comparable with those of mature fibers and were even higher than the mature fibers of Linawaan and Laylay cultivars. Fibers of abaca cv. Inosa obtained from immature stalks were thus, found suitable for pulp and paper production.
\end{abstract}

Keywords: abaca fibers, pulp and paper, chemical composition, stalk maturity

Correspondence: L. O. Moreno Address: National Abaca Research Center, Visayas State University (VSU), Baybay City, Leyte, 6521-A Philippines E-mail: lomoreno2004@yahoo.com

DOI: 10.32945/atr3423.2012 


\section{INTRODUCTION}

Abaca (Musa textilis N'ee) or Manila hemp in international trade, is indigenous to the Philippines and is one of the important export crops of the country. The Philippines is the abaca capital of the world supplying $85 \%$ of the total world abaca fiber requirement annually while the remaining 15\% is supplied by Ecuador (FiDA,2009; Philexport, 2010). The abaca industry continues to make a stronghold in both domestic and international markets generating an average of US\$ $80 \mathrm{M}$ annually from 1996-2000 (FiDA, 2010). The total export earnings from abaca fibers and manufacturers reached US\$104.5 million and US\$132.05 million in 2010 and 2011, respectively (FiDA,2011).

The abaca fiber is used in three major industries namely; cordage, pulp, as well as paper and fibercraft. The bulk of abaca fibers produced in the country is used as raw material for big pulp mills accounting for $70.2 \%$ of the total pulp consumption of an average of 36,917 metric tons from 20012005. The remaining $20.3 \%$ is used in the cordage industry and $9.5 \%$ in the fibercraft sector (FiDA, 2006; FAO, 2006). The pulp sector consistently remained as the growth area of the abaca industry utilizing $71.5 \%$ of the local consumption in 2006 (Lantican, 2008) which significantly increased to $81.5 \%$ in 2008 and $87 \%$ in 2009 (FiDA, 2010). In terms of export earnings from manufacturers for the last 10 years (1999-2008), the pulp sector contributed an average of US $\$ 41.22 \mathrm{M}$ or $51.04 \%$ share followed by fibercraft with US $\$ 12.07 \mathrm{M}(14.94 \%$ share) and cordage with US $\$ 11.85 \mathrm{M}$ (14.69\% share).

Abaca produces high quality fibers and paper sheets with acceptable strength-related properties, including breaking length, stretch and tear index, good yields and potential savings in capital equipment costs (Jimenez et al., 2005). Pulp from abaca exhibits very high tensile strength, viscosity and porosity. These properties make it the preferred raw material for the production of dielectric, bank notes, vacuum bags, tea bags, and the full range of filtration papers, hospital textiles as well as various wet laid non-wovens. It is also used to produce various art, decorative and vellum papers (Bone and Jarman, 1980; Silvario, 1976; Leatham et al, 2000). 
The pulp sector is still the actively growing part of the abaca industry contributing 70 to $80 \%$ of the total income generated by the industry (Abamo et al., 2011). Its export contribution grew largely because of the expanding demand for pulp. Despite the big contribution in the industry (export earnings and usage), very limited attention has been given to this very important sector in terms of research and policy interventions. To ensure the industry's continued stronghold in both the domestic and international markets, there is a need to raise productivity, specifically for pulp and paper.

To advance the utilization of the fiber, it is essential that fiber properties which provide for optimum performance in specialty paper manufacture be known. However, there has been very limited research on pulping characteristics, pulp yield and fiber quality of abaca. In fact, grading of abaca fibers for pulp and paper is still based on qualities used by the cordage industry such as tensile strength, color, texture, fiber length and cleaning despite the fact that more than $80 \%$ of fibers are consumed locally by the pulp sector (FiDA, 2010). In 2008, 81.5\% of the fibers produced was used for local pulp milling, which increased to $87 \%$ in 2009 (FiDA, 2010). From 1995 to 2006, the export volume and value of abaca pulp performed better than abaca fiber as reflected by its robust growth at $6.74 \%$ and $5.5 \%$, respectively (Lantican, 2008). In the country industry forecast done by Oxford Economics (2011), the pulp and paper sector would be the top five fastest growing industries of the Philippines in the next five years (2011-2015) with an average growth of 8.1\%.

Considering the increasing demand for pulp, there is a need to look into the prospects of increasing fiber production without sacrificing the quality of fibers acceptable for pulp production. It is about time to look deeper into the aspects of fiber quality obtained from younger stalks and how this would fare when used as raw material for pulp and paper manufacture. Furthermore, information on the chemical characteristics, pulp yield and pulping properties of fibers give prospective end users a good idea on the possibilities and potential of the materials for pulp and paper production. 


\section{MATERIALS AND METHODS}

\section{Preparation of Fiber Samples for Chemical Analysis and Pulping}

Abaca cv. Inosa at different stages of stalk maturity, namely; young (810 month-old), intermediate (12-14 month-old) and mature (18-24 month-old as indicated by flagleaf appearance) were harvested from Brgy. Catagbacan, Villaba, Leyte, Philippines. Fiber extraction was done using the spindle stripping machine with zero serration blade to produce $S 2$ grade fibers. Four kilograms of fibers from each stage of stalk maturity were brought to the Fiber Processing and Utilization Laboratory (FTUD) of the Fiber Development Authority (FiDA), Visayas Avenue, Diliman, Quezon City, Philippines for chemical analysis and pulping using the standard procedure of the Technical Association of the Pulp and Paper Industry (TAPPI).

\section{Fiber Chemical Properties and Solubility Determination}

The moisture and ash contents, solubilities in acetone, hot water and $1 \%$ caustic soda $(\mathrm{NaOH})$ of the fiber samples were determined following the American Standard Testing Method (ASTM). The Kurschner-Hoffer method was used for the analysis of cellulose while the standard method of TAPPI was used for the Klason lignin analysis.

\section{Pulping and Pulp Properties Determination}

The ISO (International Organization for Standardization) and TAPPI methods for pulping and pulp quality determination were used. Soda pulping of abaca fibers (S2 grade) was performed under standard conditions (TAPPI 212 om-98) using 16\% chemical charge $(\% \mathrm{NaOH})$ based on the dry weight of the fibers, at 4:1 liquor to fiber ratio, and with a cooking time of 1.5 hours from $\mathrm{T}_{0}$ to Tmax (time maximum) and 3 hours at Tmax at $170^{\circ} \mathrm{C}$. Pulping was done in a pressurized rotating digester with a cooking capacity of 3 to 3.5 kilograms dried fibers. The cold soda pulping process removes a small percentage of the lignin and hemi-celuloses from the raw materials but retains practically all of the alpha-celluloses (Villanueva etal., 1978). 
Analyses of intrinsic viscosity and Kappa number of the resulting pulp and the physical properties of the pulp handsheets were done at the Quality Control Laboratory of the Specialty Pulp Manufacturing Inc. (SPMI) located at Brgy. Hilapnitan, Baybay City, Leyte.

Preparation and Physical Testing of Pulp Handsheets

The pulp samples were subjected to beating process at different beating times $(0,5,10,15,20$ and 35 minutes). Pulp handsheet preparation and conditioning were done in accordance with ISO 5269/2-1980 (E) and TAPPI 402 standard procedures, respectively.

Experimental Design and Analysis

Standard statistical package program (SPSS Statistics 7.0) was used to compute for the analysis of variance using Pearson Correlation (2 tailed). The statistical significance of the correlation was tested using LSD, $5 \%$.

\section{RESULTS AND DISCUSSION}

\section{Proximate Chemical Composition of Fibers}

Analysis of the chemical composition of pulp serves not only to indicate whether it meets the customer's specifications but also presents to the papermaker a reliable basis for the processing of pulp into paper (Tadena and Villanueva, 1971). A proximate chemical analysis of pulp separates and quantitatively determines percentages of ash, lignin, pentosans and alpha-cellulose components in a given pulp sample. The determination involves moisture and solubility in $1 \%$ caustic soda to give significantrelationship with pulp quality.

No significant differences were observed in the chemical composition of the abaca fibers $\mathrm{cv}$. Inosa in all the three different stages of stalk maturity (Table 1). Percent moisture, ash, lignin, halocellulose, alpha-cellulose, and hemicellulose contents were comparable regardless of stage of maturity. Ash content of less than $1 \%$ is desirable for pulp and papermaking. It represents the non-volatile, non-combustible inorganic component of the fibers. 
Table 1. Chemical composition of abaca fibers cv. Inosa harvested at different stages of stalk maturity.

\begin{tabular}{lcccc}
\hline \multicolumn{1}{c}{$\begin{array}{c}\text { Chemical Composition } \\
(\%)\end{array}$} & $\begin{array}{c}\text { Young } \\
(8-10 \mathrm{mos})\end{array}$ & $\begin{array}{c}\text { Intermediate } \\
(12-14 \mathrm{mos})\end{array}$ & $\begin{array}{c}\text { Mature } \\
(18-24 \mathrm{mos})\end{array}$ & $\begin{array}{c}\mathrm{CV} \\
(\%)\end{array}$ \\
\hline Moisture & 7.50 & 7.42 & 7.26 & 7.78 \\
Ash & 0.79 & 0.40 & 0.57 & 24.53 \\
Lignin & 6.11 & 7.71 & 6.95 & 13.20 \\
Holocellulose & 93.88 & 91.89 & 95.09 & 1.05 \\
Alpha-cellulose & 70.01 & 70.09 & 71.03 & 1.62 \\
Hemicellulose & 18.49 & 17.05 & 19.72 & 7.83 \\
Solubility in (\%) & & & & \\
$\quad$ Acetone & 0.635 & 0.745 & 0.870 & 23.48 \\
$\quad$ 1\% NaOH & $13.13 \mathrm{a}$ & $14.27 \mathrm{~b}$ & $16.76 \mathrm{c}$ & 8.60 \\
$\quad$ & $0.25 \mathrm{a}$ & $0.26 \mathrm{a}$ & $0.84 \mathrm{~b}$ & 30.63 \\
\hline
\end{tabular}

Mean values in row with the same letters are not significantly different at $p \leq 0.05, \mathrm{LSD}$.

The amount of ash gives an indication of the quality of mineral matter present in the material. Higher ash content in natural fibers intended for papermaking is generally undesirable, especially if carbonates are present and the material is intended for the manufacture of dissolving pulp (Escolano, 1973).

The lignin content of fibers was not significantly different in all stages of stalk maturity. Average lignin content in young stalks was $6.11 \%$, intermediate stalk was $7.71 \%$ and mature stalk was $6.95 \%$. Lignin is an amorphous, highly polymerized substance forming the middle lamella which cements the fibers together and giving them rigidity and strength. Result of lignin analysis is frequently taken to refer to residual organic compounds resistant to most micro-biological and chemical processes. Hence, from a pulp manufacturer's point of view, lignin is considered as an undesirable component because materials with high lignin content would require higher amount of pulping and bleaching chemicals (Abdul Khalil et al., 2006) compared to those with lower lignin content. Lignin and extractives directly influence alkali consumption, delignification results and industrial production potential (Fonseca et al., 1996). 
In general, the best balance of papermaking properties occurs when most of the lignin is removed from the fibers while retaining substantial amounts of hemicelluloses and higher amounts of alpha-celluloses. Pulps with high lignin content tend to break down rather than swell during beating. They also show poor inter-fiber bonding resulting in the production of sheets with low density and strength.

No significant differences were observed as to the holocellulose, alphacellulose and hemi-cellulose contents of the fibers harvested from stalks of abaca cv. Inosa at different stages of maturity. The holocellulose or the total carbohydrate content of fibers in young stalks was $93.88 \%$ while the intermediate and mature stalks had $91.89 \%$ and $95.09 \%$, respectively. The holocellulose content in young stalks was even higher than the reported average value of $88.3 \%$ in S2 grade fibers (Escolano et al., 1971).

The alpha-cellulose content of the fiber of young stalks was $70.01 \%$, then $70.09 \%$ and $71.03 \%$ in the intermediate and mature stalks, respectively. The amount of alpha-cellulose did not significantly differ among the three stages of stalk maturity indicating that fibers from young abaca are already suitable for pulp and papermaking. The percentage of alpha-cellulose indicates the amount of cellulose in the pulp (Tadena and Villanueva, 1971). High alpha-cellulose content is not only an index of purity but also of long molecular chains indicating that the pulp is not degraded by hydrolysis or oxidation. From a chemical composition point of view, plant materials with $34 \%$ and higher alpha cellulose content are characterized as promising for pulp and paper manufacture(Nieschlag et al., 1960).

Among the different chemical characteristics of the fibers, the hemicellulose content is one of the most important from the papermaking point of view. The hemicellulose content of young Inosa stalk was $18.49 \%$ while the mature stalk was $19.72 \%$. Pulps with moderate percentage (less than $20 \%$ ) of hemicelluloses make it easier to beat that contributes to the bonding ability between fibers and produce strong sheets due to swelling effect (Lathrop, 1952; Tadena and Villanueva, 1971; Bisana et al., 1988; Browning, 1961). Furthermore, hemi-celluloses act as an adhesive within the individual fiber itself, for internal cohesion of the cell wall as well as in inter-fiber bonding (Pande and Roy, 1998). When softened and swollen, fibrillation results, producing paper of high physical-mechanical strength.

Chemical analysis showed that fibers from young stalks are already comparable to mature fibers indicating their suitability for the production of pulp and paper. 
Significant differences however were observed in terms of solubility of the fibers in hot water and $1 \% \mathrm{NaOH}$. Solubility in the above two solvents was significantly higher in fibers from the mature stalks compared to those from the intermediate and younger stalks (Table 3). Solubility in $1 \% \mathrm{NaOH}$ determines the resistance of pulp to a solution of hot dilute alkali and also measures the degree of fungal decay. The percentage of the alkali-soluble material increases as the raw fibrous material decays or degrades (Morgan, 1931; Procter and Chow, 1973).

The solubility of pulp indicates the extent of cellulose degradation during pulping and bleaching process and has been related to strength and other properties of the resulting pulp (Anderson, 1937). TAPPI standard T212 m-54 claims that the bulk of the material dissolved by the dilute alkali solution consists of pentosans or hemi-celluloses and other carbohydrates less resistant to the action of dilute alkali solution than cellulose (Tadena and Villanueva, 1971). The solubility in sodium hydroxide solution can give a preliminary indication of the content of non-cellulosic mass polysaccharides. Fibers from mature stalks were more soluble in $1 \% \mathrm{NaOH}$ compared to those from the intermediate and young stalks, indicating higher expected pulp yield.

\section{Pulping Properties and Pulp Yield}

The total pulp yield or pulp recovery was $64.86 \%$ from the young stalks, $64.96 \%$ from the intermediate stalks and $65.79 \%$ from the mature stalks. Percent acceptable pulp recovery are $64.51 \%, 64.63 \%$ and $65.49 \%$, for immature, intermediate and mature stalks, respectively. The pulp recovery of fibers from abaca cv. Inosa were higher in all the three stages of stalk maturity compared to that of both the Laylay and Linawaan cultivars (Table 2). Laylay and Linawaan, both commercially grown cultivars in Eastern Visayas region, had total pulp recovery of $62.38 \%$ and $61.77 \%$, with acceptable pulp yields of $62.23 \%$ and $61.66 \%$, respectively.

The Kappa number and viscosity of Inosa, in all three stages of stalk maturity, were also higher compared to Laylay and Linawaan. (Table 2) The average Kappa number in Inosa was 7.4, 7.0 and 7.4 in young, intermediate and mature stalks, respectively, while in Laylay and Linawaan, the Kappa number was very low at 2.4 in both cultivars. The Kappa number gives an indication of the degree of bleachability of the resulting pulp. Kappa number below 10 means that there is no need to bleach the pulp or very minimal amount of bleaching is needed (www.paperonweb.com). 
Table 2. Pulping properties and pulp yield of abaca cv. Inosa harvested at different stages of stalk maturity compared with 'Laylay' and 'Linawaan'.

\begin{tabular}{|c|c|c|c|c|c|}
\hline \multirow{4}{*}{ Parameter } & \multicolumn{5}{|c|}{ Cultivar } \\
\hline & \multicolumn{3}{|c|}{ Inosa } & Laylay & Linawaan \\
\hline & \multicolumn{5}{|c|}{ Stage of stalk maturity (months) } \\
\hline & $\begin{array}{l}\text { Young } \\
(8-10)\end{array}$ & $\begin{array}{c}\text { Intermediate } \\
(12-14)\end{array}$ & $\begin{array}{l}\text { Mature } \\
(18-24) \\
\end{array}$ & $\begin{array}{l}\text { Mature } \\
(18-24) \\
\end{array}$ & $\begin{array}{l}\text { Mature } \\
(18-24)\end{array}$ \\
\hline \multicolumn{6}{|c|}{ Pulp Recovery (\%) } \\
\hline Accepts & 64.51 & 64.63 & 65.49 & 62.23 & 61.66 \\
\hline Rejects & 0.35 & 0.33 & 0.29 & 0.15 & 0.11 \\
\hline Total & 64.86 & 64.96 & 65.79 & 62.38 & 61.77 \\
\hline Kappa Number & 7.4 & 7.0 & 7.4 & 2.4 & 2.4 \\
\hline Viscosity & 1281 & 1297 & 1344 & 705 & 712 \\
\hline
\end{tabular}

The average viscosity of Inosa was recorded to be very high at 1281 $\mathrm{mg} / \mathrm{gm}, 1297 \mathrm{mg} / \mathrm{gm}$ and $1344 \mathrm{mg} / \mathrm{gm}$ in young, intermediate and mature stalks, compared to Laylay and Linawaan with only $705 \mathrm{mg} / \mathrm{gm}$ and 702 $\mathrm{mg} / \mathrm{gm}$, respectively. This indicates that young stalks (8-10 months old) are already good materials for pulp and paper. According to Barba et al. (2002), the viscosity of commercial grade abaca fiber ranged from 1064 to 1650 while in sisal it is 525 to 804 and 600 to 850 in jute. The intrinsic viscosity (Scandinavian) is an indirect measure of polymerization of cellulose chains in the fibers or the degree of cellulose degradation of fibers during the pulping process. Longer polymer chains means thicker solution and higher viscosity or longer flow time (www.ipst.gatech.edu). Additionally, viscosity values can be used to predict expected pulp yield of a given material (Garcia et al., 2011). Hence, for industrial testing practice, viscosimetric methods like the standard flow method is quite satisfactory. Many pulp mills including the Specialty Pulp Manufacturing Inc. (SPMI) use the pulp viscosity test to predict pulp yield (personal comm.). 


\section{Physical Properties of Pulp Handsheets}

A paper sheet made from virgin pulp which has not undergone mechanical treatment is characterized by low strength, bulkiness, surface roughness and is not suitable for papermaking (Bhardwaj et al., 2004). These undesirable characteristics can be changed to a large extent by beating (Boyer et al., 2007; Bhardwaj et al., 2004) which consists of mechanical crushing and abrasion of fibers by contact with edges and faces of rapidly moving metal bars in the presence of water. Beating results to the further removal of the primary fiber walls and allows the fiber cells to hydrate or take up water and swell. Upon swelling, the fiber increases their flexibility and fiber-to-fiber bonding resulting to stronger pulp sheets. Beating or refining of pulps is an essential process of paper manufacture and is carried out to a greater or lesser degree in all paper and pulp mills.

The process of pulp and papermaking is quite complicated. A number of factors has to be considered like type of raw material to be used as well as the pulping, bleaching and beating conditions. In SPMI (personal comm.), the standard optimum of freeness in pulping is $25^{\circ} \mathrm{SR}$ (Schopper Reigler freeness) which is attained approximately after 25-30 minutes of beating.

The shortening of fiber cells during beating helps improve sheet formation contributing to paper uniformity and smoothness, however, it causes a large reduction in tearing and folding resistance of the resulting paper, a proportional reduction in the bursting strength and small reduction in tensile strength (Mosello et al., 2010). The fibers of immature stalks are softer compared to those of the mature stalks as shown by the higher freeness value $\left(14.50^{\circ} \mathrm{SR}\right)$ of the unbeaten pulp indicating that the pulp would tend to become degraded when subjected to further beating for 25-30 minutes. Pulp from fibers of immature stalks would only require shorter beating time compared to that of mature stalks to achieve the desired degree of fiber to fiber bonding without adversely reducing the quality of the resulting pulp product. Thus fibers from young stalks when mixed with fibers from the intermediate and mature stalks, would result to poor pulp quality due to pulp degradation which definitely would affect the overall quality of the resulting pulp handsheets. 
Cellulose occurs in plant cell walls as microfibrils $(2-20 \mathrm{~nm}$ diameter and 100-40,000 $\mathrm{nm}$ long) providing a linear and structurally strong framework (Akin, 2010). These fibrils can be exposed by beating or refining and provide very large area for bonding. Overall, beating improves the bonding ability of the fibers during papermaking (Lumiainen, 2000).

However, when the pulp is subjected to overbeating there would be disintegration of fibrils resulting to a decrease in tensile strength of the resulting pulp products. Cellulosic fibers in younger stalks are probably softer compared to those from the mature stalks resulting to early degradation of the pulp after 15 minutes of beating.

Pulp freeness measures the drainability of a pulp suspension and higher freeness values means slower draining pulp suspension. Freeness of unbeaten pulp in 8-10 months-old (young) abaca was higher than the 12-14 month-old (intermediate) and 18-24 month-old (mature) abaca (Table 3). Unbeaten pulp with a freeness value of 19 is an indication that it is degraded and not acceptable for pulping (personal communication, SPMI). In young stalks, the pulp freeness value was 14.50 , which means that the fibers are not yet degraded and already acceptable for pulping. Freeness value in young stalks was also significantly higher compared to intermediate and mature stalks. Higher freeness value obtained at 0 beating shows that defibrillation process has already started. This implies that the cellulose fibers are softer and could be easily degraded at increasing beating time.

Pulp freeness gives a measure of the rate at which a dilute suspension of pulp ( 3 gms of pulp in $1 \mathrm{~L}$ of water) may be drained. The freeness, or drainage rate, has been shown to be related to the surface conditions and swelling of the fibers. It is also widely used to follow the changes in drainage rate of various chemical pulps during beating and refining.

Brightness (reflectivity of light by paper) of pulp roughly correlates with whiteness and usually expressed in percent. The degree of brightness is an indicator of the bleaching formulation or amount of bleaching chemical to be used to attain the desired whiteness or brightness of the resulting pulp product to be produced. The higher the degree of brightness, the lower concentration or amount of bleaching chemical is needed to bleach the pulp.

Pulp from young stalks had $45 \%$ brightness, whereas pulp from intermediate and mature stalks had $46.4 \%$ and $44 \%$ brightness, respectively. This means pulp from young stalks already possesses the degree of brightness of pulp from mature stalks required in papermaking. 
Table 3. Physical properties of unbeaten soda pulp handsheets from abaca cv. Inosa harvested at different stages of stalk maturity.

\begin{tabular}{|c|c|c|c|c|c|c|}
\hline \multirow{2}{*}{ Parameter } & \multirow{2}{*}{ Unit } & \multirow{2}{*}{ Standard } & \multicolumn{3}{|c|}{$\begin{array}{l}\text { Stalk Maturity } \\
\text { (months) }\end{array}$} & \multirow{2}{*}{$\mathrm{CV}$} \\
\hline & & & $8-10$ & $12-14$ & $18-24$ & \\
\hline Freeness & ${ }^{0} \mathrm{SR}$ & ISO 5267 & $14.50 \mathrm{a}$ & $13.60 \mathrm{~b}$ & $13.50 \mathrm{c}$ & 8.28 \\
\hline Substance & $\mathrm{g} / \mathrm{m}^{2}$ & ISO 536 & 25.16 & 25.64 & 25.24 & 0.45 \\
\hline Density & $\mathrm{g} / \mathrm{cc}$ & ISO 534 & $0.47 \mathrm{a}$ & $0.46 \mathrm{a}$ & $0.44 \mathrm{~b}$ & 5.68 \\
\hline Porosity & $\mathrm{cc} / \mathrm{min} . \mathrm{cm}^{2}$ & ISO 2965 & $1841 \mathrm{a}$ & $1962 b$ & $2531 \mathrm{c}$ & 6.96 \\
\hline Capillary Rise & $\mathrm{mm}$ & ISO 8787 & $107 \mathrm{a}$ & $122 b$ & $114 \mathrm{ab}$ & 20.29 \\
\hline Tear Index & $\mathrm{mN} \cdot \mathrm{m}^{2} / \mathrm{g}$ & ISO 1974 & $33.10 \mathrm{a}$ & $35.60 \mathrm{~b}$ & $31.10 \mathrm{a}$ & 16.96 \\
\hline $\begin{array}{l}\text { Breaking } \\
\text { Length }\end{array}$ & $\mathrm{m}$ & ISO 1924 & 5969 & 5918 & 5803 & 3.84 \\
\hline Burst Index & $\mathrm{kPa} \cdot \mathrm{m}^{2} / \mathrm{g}$ & ISO 2758 & $3.71 \mathrm{a}$ & $3.65 \mathrm{a}$ & $3.35 \mathrm{~b}$ & 11.34 \\
\hline Brightness & $\%$ & ISO 3688 & 45.40 & 46.4 & 44.0 & \\
\hline
\end{tabular}

Mean values in row with the same letters are not significantly different at $p \leq 0.05$,LSD.

Air permeability or porosity of paper may be used as an indirect indicator of the degree of beating, absorbency, apparent specific gravity and filtering efficiency of liquids and gases. Air permeability is influenced by the internal structure and surface finish. Internal structure is controlled largely by the type and length of fibers, degree of hydration, orientation and composition of the fibers. There was a decrease in porosity of pulp handsheets in 8-10 month-old (young) stalks compared to the 12-14 month-old (intermediate) and 18-24 month-old (mature) stalks.

Soda pulp handsheets from Laylay and Linawaan cultivars were observed to have higher degree of brightness at $61.1 \%$ and $61.5 \%$, respectively, compared to 'Inosa' with only $44 \%$ (Table 4). This implies that very minimal amount of bleaching chemical is needed to bleach the resulting pulps of Laylay and Linawaan compared to Inosa in order to attain the desired whiteness of the resulting pulp handsheets. Laylay and Linawaan cultivars showed the same trend with young and intermediate stalks of Inosa in terms of physical pulp (unbeaten) properties. This means 
that fibers from young and intermediate stalks of Inosa are already comparable with the aforementioned two recommended varieties in their pulping and physical properties.

Table 4. Physical properties of unbeaten soda pulp handsheets from three commercially grown abaca cultivars in Eastern Visayas.

\begin{tabular}{|c|c|c|c|c|c|c|}
\hline \multirow{2}{*}{ Parameter } & \multirow{2}{*}{ Unit } & \multirow{2}{*}{ Standard } & \multicolumn{3}{|c|}{ Cultivar } & \multirow{2}{*}{$\mathrm{CV}$} \\
\hline & & & Inosa & Laylay & Linawaan & \\
\hline Freeness & ${ }^{0} \mathrm{SR}$ & ISO 5267 & $13.5 a$ & $13.6 b$ & $14.7 \mathrm{c}$ & 8.21 \\
\hline Substance & $\mathrm{g} / \mathrm{m}^{2}$ & ISO 536 & 25.24 & 25.32 & 25.32 & 0.45 \\
\hline Density & $\mathrm{g} / \mathrm{cc}$ & ISO 534 & $0.44 \mathrm{a}$ & $0.38 b$ & $0.38 \mathrm{~b}$ & 5.89 \\
\hline Porosity & $\mathrm{cc} / \mathrm{min}_{\mathrm{cm}}{ }^{2}$ & ISO 2965 & 2541 & 3558 & 3561 & 4.56 \\
\hline Capillary Rise & $\mathrm{mm}$ & ISO 8787 & 114 & 146 & 137 & 17.46 \\
\hline Tear Index & $\mathrm{mN} \cdot \mathrm{m}^{2} / \mathrm{g}$ & ISO 1974 & 31.10 & 30.60 & 38.0 & 16.98 \\
\hline Breaking Length & $\mathrm{m}$ & ISO 1924 & 5803 & 5456 & 5965 & 3.94 \\
\hline Burst Index & $\mathrm{kPa} \cdot \mathrm{m}^{2} / \mathrm{g}$ & ISO 2758 & 3.35 & 3.09 & 3.42 & 12.30 \\
\hline Brightness & $\%$ & ISO 3688 & 44.0 & 61.1 & 61.5 & \\
\hline
\end{tabular}

SUMMARY

Fibers from abaca cv. Inosa harvested at different stages of stalk maturity were analyzed as to their chemical composition and pulping properties to determine their suitability for pulp and paper manufacture.

Fibers of 8-10-month-old (young) abaca cv. Inosa already possess the desirable chemical properties of low lignin and ash content, high alphacellulose, holocellulose and hemicellulose contents. These qualities are already comparable with those of fibers from intermediate and mature stalks.

Abaca cv. Inosa proves to be the best abaca cultivar suited for pulp and paper at present. Its average pulp recovery was higher compared to 'Laylay' and 'Linawaan' regardless of the stage of stalk maturity. The total pulp yield from young stalks was $64.86 \%$ while the intermediate and mature stalks had $64.98 \%$ and $65.49 \%$, respectively. These values are relatively higher 
compared to Laylay (62.23\%) and Linawaan (61.66\%). In addition, the Kappa number and viscosity of Inosa in all three stages of stalk maturity were also higher compared to Laylay and Linawaan.

The breaking length and tear index of fiber cells from immature stalks decreased at 15 minutes of beating whereas those from the intermediate and mature stalks, decreased at 20 minutes of beating. Fibers from young stalks are already acceptable for pulp and paper production but should not be mixed with fibers from intermediate and mature stalks, as its results to poor pulp quality and consequently, poor paper product.

\section{CONCLUSION}

Fibers from young stalks (8-10 month-old) are already suitable for pulp and paper production. Chemical composition of fibers obtained from 8-10 months old abaca were already comparable with those from mature stalks. Pulp quality is not affected by age of stalk. Pulp yield, kappa number, viscosity, tear index and breaking length of pulps from young stalks were already comparable with those of mature fibers and were even higher than those from the mature fibers of Linawaan and Laylay cultivars. This only proves the claim that Inosa is the best cultivar for pulp and paper at present.

\section{RECOMMENDATIONS}

The present standard for fiber grading and classification which is primarily based on the standard grades and quality required by the cordage industry needs to be looked into. Fiber length and tensile strength are two of the qualities used in the existing grading system. The acceptable length of marketable fibers is not less than 1 to 1.5 meters. However, in the pulping industry, fiber length is not a requirement since all fibers are being pulped regardless of length. The pulp sector is concerned more of the length and tensile strength of the ultimate fiber cells while the cordage and fibercraft sector is after of the fiber bundle. It is high time then for the industry to take a closer look into the specific needs of these different sectors as to their specific fiber requirements and consider the idea of providing a separate grading system for the pulp industry. 
Since the harvesting of young stalks is not economically feasible, considering the low yield obtained from young stalks, it is recommended that this aspect be studied further. But during typhoons, when the young stalks are toppled down, it is advisable to strip the fibers. Although the resulting fibers from young stalks would be a grade lower than the mature stalks, it is still practical to utilize the fibers for paper and pulp making rather than leaving the stalks in the field to rot.

\section{REFERENCES}

ABAMO AP., AM MASCARIÑAS, BS VILLARIN, EG ALAN, and JR GALVE. 2011. Abaca Fiber Industry in the Philippines. In: Exploring the Opportunities Towards Competitiveness: Supply Chain Improvement of Selected Commodities in AFNR (Phase I). PCARRD, DOST, Los Baños, Laguna. $61 \mathrm{p}$.

ABDUL KHALIL HPS, M. SITI ALWANI, and AK MOHD OMAR, 2006. Chemical composition, anatomy, lignin distribution and cell wall structure of Malaysian plant waste fibers. In: Cell walls of tropical fibers. BioResources 1(2):220-232.

AKIN, DE. 2010. Chemistry of Plant Fibers. In: Mussig J, editor. Industrial Applications of Natural Fibers: Structure, Properties and Technical Applications. John Wiley and Sons, Ltd. p. 13-22.

ANDERSON, OE. 1937. Some causes for non-uniformity in sulfite pulp manufacture. Paper Trade Journal 104(6):42.

BARBA, C, D. MONTAN, M. RINAUDO, and X. FARRIO. 2002. Synthesis and characterization of carboxymethylcellulose (CMC) from non-wood fibers I. Accessibility of cellulose fibers and CMC synthesis cellulose 9:319-326.

BHARDWAJ NK, DUONG TD, and KL NGUYEN . 2004. Pulp charge determination by different methods: Effect of beating/refining. Colloids and Surfaces 239:39-44. 
BISANA, BB., MS DIONGLAY, and CA GARCIA. 1988. Proximate chemical composition of Para rubber (Hevea brasiliensis (HBK) Meull. Arg.). FPRDIJournal 17(1):1-4.

BONE RT, and CG JARMAN . 1980. Abaca for papermaking: An Atlas of Micrographs. Rep Trop Prod Inst, G. 136.36 p.

BOYER JL, R. SHMULSKY, and J. HAYGREEN . 2007. Forest Products and Wood Science: An Introduction. $5^{\text {th }}$ ed. Blackwell Publishing Asia. $554 \mathrm{p}$.

BROWNING BI. 1961. Methods of wood chemistry. Part 27. Vol. 1, John Wiley and Sons, New York. p. 75-268.

ESCOLANO, EU. 1973. The proximate chemical composition of agricultural fibrous materials and its significance. FORPRIDECOM No. 129.

ESCOLANO EU, FRANCIA PC, and JA SEMANA. 1971. Proximate chemical composition of some commercial grades of abaca fibers. The Philippine Journal of Science 100(2):107-114.

FOOD AND AGRICULTURE ORGANIZATION. 2006. Jute, Kenaf, Sisal, Abaca, Coir and Allied Fibers Statistics. Retrieved January 18, 2012. http://www.fao.org/es/esc/en/20953/21005/highlight_51023en.html

FIBER DEVELOPMENT AUTHORITY. 2009. Exports: average 1996-2000. Retrieved March 23, 2010 from http://fida.da.gov.ph /Abaca6.html.

FIBER DEVELOPMENT AUTHORITY. 2010. Fiber Market Report Vol. 7 No.1. Fiber Development Authority, Quezon City.

FONSECA SM, OLIVIERA RC, and PN SILVIERA . 1996. Selecao d arvore industrial. Revista Arvore, Vicosa 20(1):69-86.

GARCIA JC, ZAMUDIO MAM, PEREZ A, FERIA MJ, GOMIDE JL, COLODETTE JL, and F. LOPEZ 2011. Soda-AQ Pulping of Paulownia wood after hydrolysis treatment. BioResources 6(2): 971-986. 
JIMENEZ L, RAMOS E, DE LA TORRE MJ, PEREZ I, and JL FERRER . 2008. Bleaching of soda pulp of fibers of Musa textilis Nee (abaca) with peracetic acid. Bioresource Technology 99:1474-1480.

LANTICAN FA. 2008. The Philippine Abaca Industry: Status, Market Potentials, Priority Issues and Directions. Agricultural and Applied Economics Research Bulletin Vol. 2 Nos. 1 \& 2, CEM, UPLB, College, Laguna. $16 \mathrm{p}$.

LATHROP EC. 1952. The characteristics of pulp fibers from agricultural residues. Tropical Woods and Agricultural Residues as Sources of Pulp, FAO, Rome. 143 p.

LEATHAM DJ, DE PAREJA LA, SALAZAR W, and C. BOCARDO . 2000. Factores econo'micos afectando la produccio'n de abaca' en Ecuador. Retrieved February 8, 2012. In: http://

www.sica.gov.ec/agronegocios/abaca.pd

LUMIAINEN J. 2000. Refining of chemical pulp. Papermaking Science and Technology. Papermaking Part 1:Stock Preparation and Wet End. Vol. 8. Fapet Oy: Helsinki, Finland. 86 p.

MORGAN HW. 1931. Wood Evaluation for Soda Pulp Manufacture. Paper Trade Journal 92(15):51.

MOSSELLO AA, HARUN J, TAHIR P, RESALATI H, and I. RUSHDAN . 2010. A Review of Literatures Related to Using Kenaf for Pulp Production (Beating, Fractionation and Recycled Fiber). Modern Applied Science 4(9):21-29.

NIESCHLAG HJ, NELSON GH, WOLFF JA, and RE PERDUE . 1960. A search for a new fiber crops. TAPPI 43(3):193.

OXFORD ECONOMICS. 2011. Philippines: Industry Forecast. In: By Country Industry Forecasts: Winter 2011. Retrieved February 24, 2012 from http://www.proquest.com/pdqweb. 
PANDE H, and DH ROY. 1998. Influence of fiber morphology and chemical composition on the papermaking potential of kenaf fibers. Pulp and Paper Canada 99(11): 374-377.

PHILEXPORT. 2010. The Philippine Abaca Industry Situation 2002-2009. Retrieved July 3, 2010 from www.philexport.ph/sector abaca.

PROCTER AR, and WM CHOW . 1973. A Chip Quality Index for Rot. Pulp and Paper Mag. Can. 74(7):97.

SILVARIO BN. 1976. Isarog makes specialty pulps Philippine abaca fiber. Pulp and Paper International 18 (9): 36-37.

TADENA OB, and EP VILLANUEVA . 1971. Proximate chemical analysis of pulp as basis of its papermaking qualities. FORPRIDECOM Technical Note No.111.2p.

VILLANUEVA, EP., OB. TADENA and AA FAULMINO. 1978. Nondegradation treatments of abaca pulp with chlorine and peroxide compounds. NSDB Technology Journal 3(4):42-50.

Web: http://www.paperonweb.com/pulppro.htm. Retrieved March 10, 2012. 